\title{
CIMA, DE GABRIELA MISTRAL
}

\author{
POR \\ CEDOMIL GOIĆ \\ University of Michigan
}

La relación de Gabriela Mistral con la poesía de vanguardia toma variadas formas. Todas ellas muestran que desde fecha temprana se mostró atraída simpáticamente hacia la poesía nueva y que, al menos en un momento inicial, apareció identificada generacionalmente con los poetas jóvenes innovadores de los años veinte ${ }^{1}$. El modo como se relaciona con Vicente Huidobro y su poesía nos servirá de guía para historiar brevemente el significado de la nueva poesía para la Mistral y las transformaciones que experimenta su estimación de la poética creacionista. La primera relación es de amistad y de solidaridad ante el ataque que Ernesto A. Guzmán hace a Huidobro en su reseña del libro Adán en la revista Los Diez ${ }^{2}$. «Mi querido amigo Vicente Huidobro - escribe a Natanael Yáñez Silva- sufrió un ataque de Guzmán. Y no se trataba, por cierto, de un clásico, ni siquiera de un pseudoclásico» ${ }^{3}$. La apología de

${ }^{1}$ Sobre estas relaciones, véanse los estudios de Julio Saavedra Molina, Gabriela Mistral: su vida y su obra (Santiago, 1947), y de Augusto Iglesias, Gabriela Mistral y el Modernismo en Chile (Santiago: Editorial Universitaria, 1950), pp. 267285. E1 primero las atribuye a la veleidad del poeta que sigue diversas modas; el segundo las considera a la luz del irracionalismo y del predominio de lo dionisíaco. Ambos las remiten a sus consideraciones sobre Tala (1938).

2 Véase Ernesto A. Guzmán, «Adán, por Vicente Huidobro», en Los Diez, I, 1 (Santiago, septiembre 1916), pp. 78-79.

${ }^{3}$ El comentario de la Mistral en «Carta a Nataniel (sic) Yáñez Silva», en ZigZag (Santiago, 26 de enero de 1918), reproducida en Raúl Silva Castro, «Producción de Gabriela Mistral de 1912 a 1918», en $A U C h, 115,106$ (1957), p. 246. En el origen de esta simpatía está la amistad de la Mistral con María Luisa Fernández de García Huidobro (Monna Lisa), a quien dedica los Poemas de las madres y quien presidirá el Ateneo Gabriela Mistral, creado a la partida de la poetisa en 1922. Véase sobre esto Raúl Silva Castro, «Epistolario: cartas a Eugenio Labarca (19151916)», en $A U C h, 115,106$ (1957), pp. 271, 273, 274. Con motivo de su designa- 
Huidobro alcanza mayor trascendencia cuando la Mistral reseña la antología Nuestros poetas, de Armando Donoso ${ }^{4}$. En este caso se trata de separar el grano de la paja y de reducir el valor de la poesía chilena a unos pocos poetas realmente estimables. Entre éstos destaca la Mistral a Huidobro en los siguientes términos: «Se comenta mucho y tiene imitadores en toda América Vicente Huidobro, y se le niega en Chile la sal y el agua» ${ }^{5}$. Más tarde confirmará la misma apreciación de la poesía huidobriana cuando se refiera a la situación de la poesía chilena a la llegada de Neruda a Santiago: "A su llegada de provinciano a la capital, él encontró un grupo alerta, vuelto hacia la liberación de la poesía, por la reforma poética de anchas consecuencias de Vicente Huidobro, el inventor del Creacionismo» ${ }^{6}$.

Hacia 1930, la Mistral todavía conserva su entusiasmo por la poesía nueva, pero ve indudablemente reducida en la explosión de los ismos la significación de Huidobro para enfatizar la universalidad de los rasgos gregarios que la poesía nueva ha alcanzado por esa fecha. Es interesante observar para ese entonces la nueva carga semántica que alcanza la palabra Modernismo en la respuesta de la Mistral a una encuesta sobre el tema:

Si el pensamiento de mi amigo Vicenzi es el de englobar en la expresión Modernismo la tendencia de avanzada de esta hora misma, yo contestaría a su primera pregunta (¿Qué escritores cree usted que caracterizan mejor el modernismo artístico?): ningún grupo caracteriza más que el otro este movimiento; todos los grupos se sienten y se proclaman, uno para uno, el más importante: creacionismo, imaginismo, estridentismo y etc., el Diluvio. Yo me siento incapaz de orientarme en esta batahola magnífica. Gozo aquí y allá una metáfora virgínea, una síntesis felicísima, sin conseguir que la secta a que pertenece un poema me muestre contorno claro y me deje fijarla como una línea climatérica en un mapa ${ }^{7}$.

Una primera reticencia en su valoración de la poesía nueva se percibe claramente en la observación de que en los últimos cinco años la poesía

ción Monna Lisa escribe: «Acepto y agradezco el honor que me hacen asociando mi nombre al de Gabriela Mistral, que es para mi la primera mentalidad femenina del habla castellana» (Cf. Virgilio Figueroa, La Divina Gabriela, Santiago, 1933, pp. 96-97).

${ }^{4}$ Armando Donoso, Nuestros poetas (Santiago, 1925).

${ }^{5}$ Gabriela Mistral, «Nuestros poetas», en Recados contando a Chile (Santiago: Editorial del Pacífico, 1957), p. 11.

"Gabriela Mistral, «Recado sobre Pablo Neruda», en Recados contando a Chile, p. 165.

${ }^{7}$ Citado por Virgilio Figueroa, op. cit., p. 192. 
nueva no ha producido un poema de la calidad de algunos de Rubén Darío. Cree, con Ortega y Gasset, «que el poema de tipo ultraísta o creacionista o dadaísta que pueda llamarse jefe, o al menos representativo de la corriente, no nace todavía. Estamos esperándolo hace unos cinco años muchos, y con bastante buen deseo de que su poesía se aúpe a nivel del Responso a Verlaine o de La Cartuja ${ }^{8}$. No tenemos un juicio de la Mistral sobre Altazor, publicado un año más tarde, pero dudamos que de verlo como poema jefe de la poesía nueva pudiera verlo al mismo tiempo como poema al nivel de los de Darío. Aquí se revela manifiestamente una incomprensión y fatiga de la Mistral por el tipo de poema que ha caracterizado la poesía nueva desde 1916 hasta 1930. Agreguemos que los cinco años a que se refiere envuelven el al menos aparente silencio que sigue a la publicación de los libros franceses de 1924 - Tout a coup y Automne régulier- de Vicente Huidobro. El tipo de poema queda suficientemente ilustrado como rasgo dominante de la antología de Hidalgo, Huidobro y Borges, Indice de la nueva poesía americana, de $1926^{9}$.

Un nueva y más agresiva toma de posición frente a la poesía nueva aparecerá condicionada por el advenimiento de la segunda generación contemporánea, que recupera en una nueva situación el mundonovismo mistraliano, un determinante tenaz de la comprensión poética de la Mistral.

Corrimos grandes riesgos en el Pacífico, cuando los futurismos cayeron en alta marea sobre nuestros valles ingenuos. Los mozos recibían esa marejada de pie y con los brazos abiertos, sin reservas y sin defensa; no querían sino perderse, como unos Ulises sin Penélopes. La sensibilidad, la lengua poética y el repertorio de temas que traía la avalancha tenían poco o nada que hacer con nosotros. Ellos habían partido del Mediterráneo, de la Mancha, del Atlántico yanqui... de Kamanchatka (según el chiste de Cocteau, tal vez hasta de Casiopea, de todas partes menos de nuestras propias entrañas). Aquello era un furor de extranjería, una especie de rabia contra nosotros mismos. Fue el primer momento de la poesía nueva» ${ }^{10}$.

${ }^{8}$ Citado por Virgilio Figueroa, op. cit., p. 193. Parece hacer eco a las palabras de Ortega y Gasset en La deshumanización del arte (1925): «Se dirá que el arte nuevo no ha producido nada que merezca la pena, y yo ando muy cerca de pensar lo mismo» (O. c., t. III, 1950, p. 386).

'Indice de la nueva poesía americana, prólogo de Alberto Hidalgo, Vicente Huidobro y Jorge Luis Borges (Buenos Aires: Sociedad de Publicaciones El Inca, 1926).

${ }_{10}$ Gabriela Mistral, «Recado para Julio Barrenechea», en Recados contando a Chile, p. 218. El mismo comentario esquivo y burlón está ya en su artículo «Poe- 
Estará claro que ese furor de extranjería sólo se ilumina desde un furor de autoctonía. Este es el que determina las limitaciones de la comprensión mistraliana de la primera generación, y en ella, en especial, de la poesía de Huidobro.

Otra reserva, esta vez formal, se refiere a la gravitación esencial que la primera vanguardia y el creacionismo asignaron a la imagen. Esa suerte de absolutismo de la creación pura encuentra poco eco en la Mistral: «Dicen que el poeta vale lo que valen sus metáforas. No voy tan lejos. Que va vestido de ellas y que ellas le dan la gesticulación, eso sí; pero que sean ellas y únicamente ellas ya me parece otra cosa» ${ }^{11}$.

El elogio del acriollamiento de la imagen en la poesía de la segunda generación señala los límites precisos de la comprensión mistraliana de la nueva imagen: «La metáfora en usted - dice refiriéndose a Julio Barrenechea- no parece tan lejana que venga ni del cielo empírico ni del remoto limbo. Algo del acérrimo realismo chileno subsiste en ellas y las racionaliza todo lo que es necesario para que no estén en el poema a título de puros droleries o de burlas del poeta con el resabido fariseo» ${ }^{12}$. Al mismo tiempo cree reconocer los indicios de un agotamiento de las posibilidades de la imagen sorprendente preconizada por la vanguardia: «Porque escandalizar con la imagen por puro desparpajo es cosa que ya va pasando, que se ha gastado. A estas alturas del tiempo ya no pasma ni alborota ni la metáfora más insensata: comienza a dar tedio porque ha agotado sus recursos para asombrar» ${ }^{13}$.

En medio de esta toma de posición es importante consignar las relaciones más directas que la obra de Gabriela Mistral pudo tener con la poesía nueva a la hora de la publicación de su primer libro. Si nos volvemos a situar en las vísperas de la publicación de Desolación, es de preguntarse si esta mujer enormemente curiosa de la literatura y de la poesía nuevas cedió, más allá de sus comentarios entusiastas y sus reservas, a la fuerza seductora de la poética nueva. Creemos que sí cedió, que más allá de su personal capacidad innovadora, que alcanza momentos notables en su libro, hay una serie de poemas, escritos y publicados entre

ma de Neruda»: «La poesía nueva tiene siempre en torno el rezongo del lector común; él no entiende, él quiere entender, y como no logra mucho, rabia y acaba por negar. La poesía nueva es una contorsión, una colección de tics nerviosos; en el mejor caso, una gaya payasada. Cada día yo sé mejor que eso es una Poesía, ni la única, como ellos, los «nuevos», quieren, ni la primera, ni la última que echa vagido en el aire del mundo» (El Mercurio, Santiago, 10 de diciembre de 1934; citado por Julio Saavedra Molina, op. cit., p. 75).

"Gabriela Mistral, «Recado para Julio Barrenechea», p. 222.

12 Ibid.

${ }^{13}$ Loc. cit., p. 223. 
1919 y 1922, que muestran los rasgos distintivos de la poesía nueva. $Y$ que hay al menos un poema en el cual es reconocible el tipo de los poemas creacionistas de Huidobro. Muy lejos de nuestro ánimo está el presentar el caso como una influencia subordinadora. Gabriela Mistral recoge dialógicamente los rasgos de la nueva poesía en un poema singular, cabalmente articulado dentro de los determinantes de su propia poética. Se trata del poema «Cima», publicado en el mismo número de la revista Nosotros, de Buenos Aires, en que Francis de Miomandre, Guillermo de Torre y Jorge Luis Borges, separadamente y cada quien a su manera, dan cuenta de la nueva poética ${ }^{14}$, analizando uno el reciente libro de Jean Epstein, aprovechando el otro la reseña del mismo libro para castigar a Huidobro y el último escribiendo el manifiesto del Ultraísmo. Lo que nos interesa considerar entonces es la cercanía que guarda (y la inevitable distancia) la relación de Gabriela Mistral con la poética de la primera vanguardia.

\section{I M A}

I. La hora de la tarde, la que pone su sangre en las montañas.

II. Alguien en esta hora está sufriendo; una pierde, angustiada, en este atardecer el solo pecho contra el cual estrechaba.

III. Hay algún corazón er donde moja la tarde aquella cima erisangrentada.

IV. El valle ya está en sombra y se llena de calma.

Pero mira de lo hondo que se enciende de rojez la montaña.

V. Yo me pongo a cantar siempre a esta hora mi invariable canción atribulada. ¿Seré yo la que baño la cumbre de escarlata?

VI. Llevo a mi corazón la mano, y siento que mi costado mana.

${ }^{14}$ Francis de Miomandre, «Crónica de la vida intelectual francesa», en Nosotros, 15, 151 (Buenos Aires, diciembre de 1921), pp. 474-481; Guillermo de Torre, «Las revistas: problemas teóricos y estética experimental del nuevo lirismo», en loc. cit., pp. 545-556; Jorge Luis Borges, «Ultraísmo», en loc. cit., pp. 466-471. 
El poema «Cima», con el título «Cima ensangrentada», se publicó por primera vez en la revista Nosotros, año XV, núm. 151, Buenos Aires, diciembre de 1921, pp. 450-451. Aparece datado al pie «Cordillera, 1921». Se publicó también en Prisma, revista internacional de poesía, vol. I, núm. 4, París, abril de 1922, p. $212^{15}$. En el mes de agosto de 1922 se recoge en la primera edición de Desolación, Nueva York, Instituto de las Españas, 1922, hecha bajo el cuidado de Federico de Onís. Aparece allí con dos variantes: una, la ya mencionada del título; la otra es la eliminación del signo de exclamación que cerraba el poema en las publicaciones anteriores. Aparte de las mencionadas existe una versión musical del poema: Cima, arreglo para canto y piano de Alfonso Leng, Santiago de Chile, Ediciones «Revista de Arte», 1934.

La variante más significativa de este poema afecta a su título, del cual elimina la especificación no sólo por lo que dice Gastón Figueira: «'Cima' llevó en un tiempo el título de 'Cima ensangrentada', especificación que la autora suprimió, sin duda pensando que ya está bien reflejada en el curso del poema» ${ }^{16}$, sino también porque, liberada de la especificación, la palabra «cima» adquiere una nueva libertad connotativa, un espacio de gran visibilidad, de elevación extrema, una forma de culminación, una situación límite, y porque se hace visible en el sonido

${ }^{15}$ De esta revista se tiene escasa información. Cito la reseña de su primera publicación, aparecida en Nosotros, 16, 153 (Buenos Aires, febrero de 1922), p. 288: «Dirigida por Rafael Lozano ha comenzado a publicarse en París y Barcelona una revista internacional de poesía. Aparece - dice en su página inicial- con el objeto de provocar un renacimiento en la poesía castellana.

En todas las lenguas importantes del mundo existen revistas dedicadas exclusivamente al fomento de la poesía lírica.

Solamente en castellano falta una que sepa unir a todos los poetas que escriben en la lengua de veintidós naciones y que sea capaz de concretar las aspiraciones comunes.

En todo el mundo, después de la gran guerra, se siente un inmenso deseo de renovación y actividad, sobre todo en lo que atañe a la poesía lírica.

Prisma intenta servir de portavoz a esta aspiración universal dando a conocer en castellano todas las tendencias mundiales de la poesía y sirviendo de centro en especial a todos los poetas de lengua castellana y en general a todos los poetas del mundo entero.

¿Por qué Pri[s]ma?

Porque como el prisma expone los colores del expectro (sic), Prisma mostrará toda la fama de la poesía lírica,»

${ }^{16}$ Gastón Figueira, De la vida y de la obra de Gabriela Mistral (Montevideo, 1959, p. 51), y la última de las notas, con referencia imprecisa que se perfecciona en la reelaboración del capítulo pertinente, en Gastón Figueira, «La depuración estilística en Gabriela Mistral», en Cuadernos Israelies, en Homenaje a Gabriela Mistral, IV (1960), 77. 
y la prosodia de-la palabra su tono ascendente y descendente, la forma de la cima, y en la vocal acentuada y aguda el ápice de la montaña, la punta de la lanza o de la espada.

El poema lleva el número seis en la sección «Naturaleza». En el grupo de once poemas, algunos de varias partes, es una pieza única que forma conjunto con "Otoño», "La montaña de noche» y «E1 Ixtlazihuatl». por la reiteración de las imágenes del ocaso y el motivo de.las montañas y por formar con ellos los símbolos de la vida ardiente y la rojez de la sangre frente a la blancura y la negrura de la muerte, asociadas en la visión del paisaje.

La sección se caracteriza en general por las intensas relaciones que se establecen entre hombre y naturaleza. La visión de una realidad mágica es más exclusiva en "Cima» que en los demás poemas afines, en los que es más esporádica e incidental. En ambos aspectos afecta a la postulación misma de la realidad, a su concepción de las cosas, a su dimensión representativa. En poemas de otras secciones del libro podemos ver la proposición de interrelaciones semejantes, pero limitadas al deseo o a lo posible, como se puede ver en «Balada» o en «Dios lo quiere».

Por su estructura poética, sin embargo, «Cima» constituye un ejemplo único en Desolación, que sólo por imágenes parciales se agrupa con los poemas afines de la sección y del libro. Su singularidad nace del tributo que rinde a las formas de la poesía nueva, lo que se percibe especialmente en la estructura de las imágenes y en la disposición del poema ${ }^{17}$.

Desde el punto de vista de su versificación, se trata de un poema poliestrófico suelto de 18 versos, dispuestos en seis estrofas de 2 y 4 versos $-2 / 4 / 2 / 4 / 4 / 2$ - cuya alternancia regular se altera al final. Los versos son de once y siete sílabas, y se distribuyen en forma alternada o en pares de once o de siete sílabas $-11,7 / 11,7,11,7 / 11,11 / 7,7,11,7 / 11,11$, $7,7 / 11,7$ - Como se puede observar, independientemente de su distribución estrófica hay dos grupos de igual distribución -11,11,7,7,11,7que siguen a la alternancia inicial de endecasílabos y heptasílabos.

La rima es asonante, -a-a, en los versos pares. Los versos impares van

${ }_{17}$ La crítica ha comentado brevemente el contenido de este poema. Véanse Sidonia Carmen Rosenbaum, Seven Women Poets of Spanish America (New York: Hispanic Institute, 1945, pp. 190-191); Hans Rheinfelder, Gabriela Mistral. Motive ihrer Lyrik (München, 1955, pp. 57-58), y «Gabriela Mistral», en AUCh, 115, 106 (1957), 47; Cora Santandreu, «Aspectos del estilo en la poesía de Gabriela Mistral», en $A U C h, 115,106$ (1957), p. 152; Raúl Silva Castro, Estudios sobre Gabriela Mistral (Santiago: Zig-Zag, 1935, p. 85); Martin C. Taylor, Sensibilidad religiosa de Gabriela Mistral (Madrid: Gredos, 1957, p. 221). 
sueltos, pero dan lugar a rimas ocasionales entre ellos - $\mathrm{AbCbCbDBDb}$ $\mathrm{EbDBfbCb}$-, igualmente asonantes en -e-o, -o-a. Hay además varias rimas internas. La rima interna aparece favorecida por la regularidad acentual de los endecasílabos con acento en la sexta sílaba, coincidente con el acento rítmico del heptasílabo. La rima interna más interesante es la dispuesta en quiasmo en los versos 13-14: -a, -o-a; -o-a, -a-a. También es destacable sobre el plano sonoro dominante de las rimas en -o y en -a la rima en altura creciente de la serie anterior -e-e, -i-a, que entran en cada caso en relaciones de contraste con las rimas vecinas o de semejanza total. Las pausas de los versos coinciden con las pausas sintácticas. El tono de los versos es ascendente descendente, como corresponde a oraciones o frases aseverativas. Salvo en la pausa interior del verso 1, que es de tono ascendente como correspondiente al tono de la prótasis, que imita la forma de la interrogación, y a la que sigue el tono descendente correspondiente a la apódosis:

La hora de la tarde, $\uparrow$ la que pone $/ \downarrow$ su sangre en las montañas $/ / \downarrow$

Otro tanto acontece en el verso 16, que completa una frase interrogativa.

El poema está dividido en dos partes, que comprenden las estrofas I-III y IV-VI, respectivamente. Cada una de ellas, a su vez, contiene tres momentos, que corresponden: 1) a la determinación temporal; 2) a la insinuación de una causalidad, y 3) a la formulación de una certidumbre o verificación de que la causalidad insinuada es efectiva. La estructura paralela del poema presta convicción a la formulación de una causalidad mágica con que se redondea el texto.

Cada uno de los momentos de cada parte establecen entre ellos relaciones de oposición bien definidas. Así, entre las estrofas I y IV, caracterizadas por proporcionar sendas determinaciones temporales, se opone el carácter puntual de la primera al carácter progresivo de la segunda. Esta última propone además la presencia contrastada de la sombra frente a la luz, de la hondura frente a la altura y de la calma frente a la actividad, que en el fondo contraponen la presencia humana al fenómeno cósmico, el valle a la montaña.

Las estrofas II y IV, en cada parte, contraponen la indefinición pronominal (Alguien, una, algún corazón) a la definición pronominal de un yo (Yo, seré yo, llevo a mi corazón, siento que mi costado mana). Este último se revela también como el centro del campo mostrativo (esta, este, aquella, esta, ya) y de la enunciación de un presente que coincide con el acontecer representado. 
También se oponen el carácter puramente adivinatorio de la insinuación en la primera parte y la experiencia fundada que revela la sorprendente causalidad al hablante de las estrofas III y VI.

Un paralelismo fundamental se establece por semejanza en la insinuación, estrofas II y V, entre el sufrir indiferenciado de los hombres y el cantar del poeta (que les presta voz), que los hace víctimas por igual del mundo que los hiere e iluminadores de él.

Si prestamos atención ahora a las imágenes, observamos que en ellas y en las relaciones que guardan entre sí reside lo más singular e innovador de este poema. Se trata de tres imágenes que constituyen representaciones figuradas de carácter insólito. Su extrañeza proviene de postular una visión de la realidad que hace violencia a la interpretación ingenua o natural de los hechos y establece un orden de relaciones mágico o fantástico ajeno a la experiencia ordinaria de lo real. Las imágenes están dispuestas en lugares significativos en el texto del poema, al comienzo de él, al promediar y al finalizar éste. Estos son los lugares en donde se dan desviaciones semánticas. El resto del texto, salvo menores sustituciones metonímicas, no está marcado por desviaciones. Los momentos no marcados contienen los elementos sugestivos o insinuativos de donde derivan las mágicas figuraciones de las imágenes de las estrofas III y V-VI.

La imagen primera proporciona el dato original y próximo que suscitará las adivinaciones ulteriores del hablante:

\section{La hora de la tarde, la que pone su sangre en las montañas.}

Aunque comprendemos de inmediato que la aposición especifica la luminosidad rojiza del atardecer a la puesta del sol, el lenguaje poético postula algo diferente mediante una imagen de impertinencia. Lo que aquí acontece es una desviación en relación a la representación ordinaria de la hora que importa salvar para comprender la dimensión mágica del poema, sin la cual éste dejaría de ser lo que es. En el plano de superficie estamos ante una predicación verbal impertinente en relación al sujeto. En el plano profundo observamos que ambos términos tienen implicaciones contradictorias entre sí. Por un lado rasgos semánticos: animado, corpóreo, espacial versus inanimado, incorpóreo, temporal. Lo que la imagen opera es una transferencia semántica que superpone y desplaza los rasgos pertinentes a la base del sujeto. Se opera esencialmente una animacio̊n del sujeto inanimado. En otras palabras: el sujeto se comporta, merced a esta transferencia, como si fuese animado, corpóreo 
y espacial, sin dejar de ser lo que es. Se diría que la imagen no tiene mayor complicación y la explicación es ya excesiva. Lo que nos interesa mostrar en realidad es su condicionamiento de los momentos siguientes del poema y de sus imágenes.

La segunda imagen se complica en una triple complicación:

III. Hay algún corazón en donde moja la tarde aquella cima ensangrentada.

En la primera imagen teníamos rasgos semánticos contradictorios que, podemos decir ahora, mostraban al menos un rasgo redundante, tiempo y espacio dimensionalmente cósmicos. En esta imagen, al contrario, se percibe la contradicción de cósmico versus no-cósmico, fuerte en su dimensionalidad relacionada con la pregunta por el origen. Existe, por otra parte, la animación anterior como figura continuada, aunque conducida a un grado más específico de humanización de la tarde por las implicaciones semánticas de la predicación verbal, la que, por otra parte, instrumentaliza el complemento directo. Esta figura animada, entonces, hace de la cima un instrumento o arma que acaso la tarde moja o clava en algún corazón. Es una imagen notable que alegoriza una situación postulando una relación causal efectiva entre lo humano y lo cósmico, entre el dolor humano y lo que sería su expresión cósmica. La imagen inicial de simple proyección exterior del dolor es seguida en la segunda por la visión de una activa victimación de lo humano por lo cósmico.

La imagen final cierra el ciclo de este progresivo transformarse de la serie de figuras:

V. Yo me pongo a cantar siempre a esta hora mi invariable canción atribulada. ¿Seré yo la que baño

la cumbre de escarlata?

VI. Llevo a mi corazón la mano, y siento que mi costado mana.

En la progresión inicialmente indicada, animación, humanización vienen a parar en personificación. En este punto, el yo que canta se pregunta, motivado por la similitud que la iteratividad del canto tiene con la de la hora del sol poniente, si no estará él en el polo victimado de la relación entre humano versus no humano que ha sido postulado. La respuesta viene con la sorprendida constatación de que su costado está 
herido, o sea, de que la causalidad insinuada es efectiva. Lo que previamente se ha supuesto en relación al origen de los signos sangrientos en la montaña, su origen humano, adquiere ahora la certidumbre de la experiencia personal. El cantor pone el dato convergente, por un lado, con la hora, su iteración y su efecto en el mundo, y luego lo desarrolla en una segunda convergencia que hace del cantor un miembro de la humanidad victimada por el mundo. Expresión del dolor y victimación de lo humano encuentra correspondencia con la hora del sol muriente y el encendido color de la montaña. Humanización de lo cósmico y cosmización de lo humano son las transformaciones fundamentalmente operadas.

Un paso más nos pone en la proyección metafórica de las imágenes y las situaciones implicadas que nos conduce a dos alegorías definidamente mistralianas. La imagen de la estrofa I se corresponde con la imagen no marcada de la estrofa $V$, versos 13 y 14. Indicada ya la iteratividad y la coincidencia horaria, la semejanza debe extenderse ahora a los verbos. Así surge el paralelismo del poner su sangre en la montaña y del ponerse a cantar su invariable canción atribulada. Expresión cósmica y expresión humana son recogidas en la montaña y en la canción en términos equivalentes de dolor. La alegoría inmediatamente suscitada es la de un Cristo y un lienzo de Verónica que reproduce la expresión dolorida.

Alterna con la anterior la alegoría del corazón de Cristo, traspasado por la lanza de Longinos (San Juan, 19,34). Así podemos hacer las sustituciones paradigmáticas biunívocas entre: un corazón-Cristo en donde moja-clava la tarde-Longinos aquella cima-lanza ensangrentada. Y del mismo modo practicar esta operación entre: yo cantor-Cristo baña la cumbre-lanza de escarlata con la sangre que la tarde-Longinos hace manar de su costado.

En esta lectura metafórica se reúnen dos elementos míticos fundamentales de la concepción poética de Mistral. Ambos proporcionan las imágenes de la pasión que más efectivamente ilustran la intensidad de su poética. Por esta vía el texto se transforma en un poema sobre la poesía, específicamente marcado por la referencia que se despliega en los versos 13-14 de la estrofa $\mathrm{V}$. La convergencia de los significados representados en el poema antes y después de esa marca llena de sentido la poética de la sangre que domina la concepción mistraliana de Desolación $^{18}$. Lo confirman las prosas de la sección «El arte», de la primera

\footnotetext{
${ }^{18}$ Martin C. Taylor (op. cit., p. 180 y ss.) desarrolla la comprensión de una "poética del sacrificio», a la que señala un fundamento teosófico, en la obra de Annie Besant, Esoteric Christianity (Adyar y Los Angeles, 1913, pp. 180-236).
} 
edición, que vienen a ser la teoría sumaria, cuando no la paráfrasis, de lo que hemos' visto representado en el poema. De «La Belleza» bastan estos fragmentos de una síntesis heroica:

Una canción es una herida de amor que nos abrieron las cosas.

Una canción es una respuesta que damos a la hermosura del mundo. Y la damos con un temblor incontenible, como el tuyo delante de un seno desnudo.

Y de devolver en sangre esta caricia de la Belleza, y de responder al llamamiento innumerable de ella, vamos más flagelados que tú [hombre basto y sensual] ${ }^{19}$.

La perfecta paráfrasis del poema que nos interesa puede encontrarse en la prosa «El canto»:

Una mujer está cantando en el valle. La sombra que llega la borra; pero su canción la yergue sobre el campo.

Su corazón está herido, como un vaso que se trizó esta tarde en las guijas del arroyo. Mas ella canta; por la escondida llaga se aguza pasando la hebra del canto. En una modulación la voz se moja de sangre.

En el campo ya callan por la muerte cotidiana las demás voces, y se apagó hace un instante el canto del pájaro más rezagado. Y su corazón sin muerte, su corazón vivo de dolor, ardiente de dolor, recoge las voces que callan en su voz.

¿Canta para un esposo que la mira calladamente en el atardecer, o para un niño al que su canto endulza? ¿O cantará para su propio corazón, más desvalido que un niño solo al amanecer? ${ }^{20}$.

Las concordancias dentro del libro pueden extenderse a las imágenes de los poemas de la misma sección de «Cima» o de las secciones restantes:

Y es lienzo de Verónica la estrofa dolorida itodo libro es purpúreo como sangrienta rosa!

(«Mis libros»)

$\mathrm{y}$ unas tardes trágicas

como Cristo, con que sangrar.

(«Canción de los que quieren olvidar»)

\footnotetext{
${ }^{19}$ Cito por Gabriela Mistral, Desolación (Buenos Aires: Espasa-Calpe Argentina, Col. Austral, 1.002), p. 197.

${ }^{20}$ Ibider.
} 
Pecho, el de mi Cristo

más que los ocasos

más ensangrentado.

(«Canto del justo»)

$\mathrm{Y}$ en la misma sección «Naturaleza»:

$Y$ en la llanura blanca, de horizonte infinito miro morir inmensos ocasos dolorosos.

(«Desolación»)

Que la tarde quebró un vaso de sangre sobre el ocaso.

(«La montaña de noche»)

Imágenes estas que están más cerca de la poesía nueva, como puede verse comparándolas con las siguientes imágenes del ocaso que seleccionamos en el Indice de Hidalgo, Huidobro y Borges:

El silencio se abrió como una llaga

(F. L. Bernárdez, «Ocaso»)

En el poniente pobre

la tarde mutilada

rezó un Avemaría de colores.

(J. L. Borges, «Atardecer»)

La poética mistraliana, explícitamente formulada en 1922, no se asocia a los términos de la poesía nueva. Muy al contrario de la creación pura, sostiene una fundamental «impureza» al afirmar la contaminación confesional con la pasión personal temáticamente desarrollada en su libro. Ese importante elemento de la cercanía de lo biográfico a la representación poética se recoge en su «Voto», que cierra Desolación en forma inequívoca:

Dios me perdone este libro amargo, y los hombres que sienten la vida con dulzura me lo perdonen también.

En estos cien poemas queda sangrando un pasado doloroso en el cual la canción se ensangrentó para aliviarme ${ }^{21}$.

El «Decálogo del Artista» expresa la misma relación en el mandamiento VI, que reafirma la función catártica de la poesía. Todo el «de-

${ }^{21}$ Op. cit., p, 239. 
cálogo» está traspasado por la concepción poética, que define la poesía en términos de transparencia representativa y expresiva sometidas a valores. La verdad, la seriedad, la limpieza moral, la sinceridad, la intensidad agónica de la existencia auténtica y vigilante constituyen condiciones determinantes de la poesía mistraliana. En correspondencia con ello, el yo lírico se configura como un yo personal, emocionalmente apasionado y de movimientos coherentes, aunque ocasionalmente marcados por la desmesura. La opacidad de la construcción de un hablante insólito no es, sin embargo, ajena a la poesía de Desolación, como lo ilustra el poema «Canto del justo». El lenguaje poético tiende a la cercanía a la lengua hablada en oposición a la afectación modernista; busca lo natural y sencillo en lugar de lo extraño y lujoso; produce la imagen de semejanza en vez de la imagen ornamental o rara; adhiere a la versificación métrica con algunas concesiones a irregularidades elaboradas. Estos rasgos son en lo dominante los rasgos de la poesía Mundonovista vigente en los años veinte. El Mundonovismo supera por reacción sencillista y americanista la artificiosidad y el cosmopolitismo esteticista del Modernismo ${ }^{22}$. En estas características se encontrarán las limitaciones mistralianas para cualquier asunción de las formas de la poesía nueva. En diálogo con ellas se desenvolverá la creación poética mistraliana. La posibilidad entonces de que una poética innovadora se abra camino en medio de la poética profundamente interiorizada de la Mistral tiene que encontrar condiciones muy severas para originar una síntesis nueva y singular. Otra cosa sería dar cabida a la imitación servil y al juego que repugnan a su concepción poética y ponen límite a la comprensión de la poesía de vanguardia ${ }^{23}$. El poema "Cima» nos parece ilustrar perfectamente esta síntesis de innovación y tradición en la poesía mistraliana de su primer libro.

${ }^{22}$ No se olvide, sin embargo, la distancia que la Mistral guarda, con todo, con su propia generación: "Vino en nuestra generación una repugnancia exagerada hacia el himno largo y ancho, hacia el tono mayor. Llegaron las flautas y los carrizos, ya no sólo de mạiz, sino de arroz y cebada... El tono menor fue el bien venido, y dejó sus primores, entre los que se cuentan nuestras canciones más íntimas y acaso las más puras. Pero ya vamos tocando el fondo mísero de la joyería y de la creación en acónitos. Suele echarse de menos, cuando se mira a los monumentos indígenas o la Cordillera, una voz entera que tenga el valor de allegarse a esos materiales formidables» [Gabriela Mistral, Tala (Buenos Aires: Sur, 1938). Nota a «Dos himnos»].

${ }^{23} \mathrm{La}$ que dice: «El poema creacionista se compone de imágenes creadas, de situaciones creadas, de conceptos creados; no escatima ningún elemento de la poesía tradicional, salvo que en él dichos elementos son íntegramente inventados, sin preocuparse en absoluto de la realidad ni de la veracidad anteriores al acto de realización.» Vicente Huidobro, «El creacionismo», en O. c. (Santiago: Andrés Bello, 1976), tomo I, p. 733. 